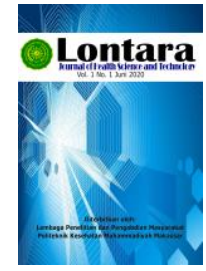

http://jurnal.poltekkesmu.online/lontarariset

Vol 2, No. 2, Desember 2021, pp 96-105

p-ISSN:0000-0000 dan e-ISSN: 2721-6179

DOI: https://doi.org/10.53861/lontarariset.v2i2

\title{
FORMULASI SABUN CAIR DENGAN KOMBINASI MINYAK KELAPA MURNI (VCO) DAN EKSTRAK DAUN MIANA (Coleus atropurpureus)
}

\author{
Anita, Nurul Ni'ma Azis, Darmawaty Rauf, Salwa Sahur \\ Teknologi Laboratorium Medis, Politeknik Kesehatan Muhammadiyah Makassar, \\ Indonesia \\ Email: anitadinar1983@gmail.com
}

\begin{tabular}{l}
\hline \multicolumn{1}{c}{ Artikel info } \\
\hline \\
Artikel history: \\
Received; 03-09-2021 \\
Revised: 22-10-2021 \\
Accepted; 24-11-2021 \\
\hline
\end{tabular}

Keyword:

Liquid soap, miana leaf extract, virgin coconut oil $(\mathrm{VCO})$

\section{Kata Kunci:}

Sabun cair, esktrak daun miana, minyak kelapa murni (VCO)

\begin{abstract}
Saponification between alkaline salt and virgin coconut oil (VCO) will produce liquid soap. This is because the use of virgin coconut oil (VCO) in saponification is known to be very good because of the presence of lauric acid which has clean power and functions as an antimicrobial. The addition of miana leaf extract (Coleus atropurpureus) in the manufacture of liquid soap because it contains flavonoids, tannins, saponins, essential oils which also function as moisturizers and antioxidants. The purpose of this study was to determine the effectiveness of the best combination of pure coconut oil (VCO) liquid soap with variations in the concentration of miana leaf extract (Coleus atropurpureus) in reducing free radicals in the form of bacteria. In this study, a laboratory experimental method was used with the addition of miana leaf extract. $A=0 \%(w / w), B=10 \%$ $(w / w), C=15 \%(w / w)$ ) ) in $100 \mathrm{~mL}$ total virgin coconut oil (VCO) three times. The test parameters were in the form of a bacteriological test using the Total Plate Number (ALT) method. From the results of the study, it was found that the formulation of pure coconut oil (VCO) liquid soap with various concentrations of miana leaf extract (Coleus atropurpureus) could reduce free radicals such as bacteria.
\end{abstract}

Abstrak. Saponifikasi antara garam alkali dan minyak kelapa murni (VCO) akan menghasilkan sabun cair. Hal ini disebabkan karena penggunaan minyak kelapa murni (VCO) dalam penyabunan diketahui sangat baik karena adanya asam laurat yang memiliki daya bersih dan berfungsi sebagai antimikroba. Penambahan ekstrak daun miana (Coleus atropurpureus) dalam pembuatan sabun cair karena memiliki kandungan flavonoid, tanin, saponin, minyak atsiri yang juga berfungsi sebagai pelembab dan antioksidan. Tujuan dari penelitian ini adalah untuk mengetahui efektifitas kombinasi terbaik sabun cair minyak kelapa murni (VCO) dengan variasi konsentrasi esktrak daun miana (Coleus atropurpureus) dalam menurunkan radikal bebas berupa bakteri. Pada penelitian ini digunakan adalah metode eksperimen laboratorium dengan perlakuan penambahan ekstrak daun miana $\mathrm{A}=0 \%(\mathrm{~b} / \mathrm{b}), \mathrm{B}=10 \%(\mathrm{~b} / \mathrm{b}), \mathrm{C}=15 \%(\mathrm{~b} / \mathrm{b})$,) dalam total minyak kelapa murni (VCO) $100 \mathrm{~mL}$ sebanyak tiga kali ulangan. Paramater uji yang dilakukan berupa uji bakteriologis dilakukan menggunakan metode Angka Lempeng Total (ALT). Dari hasil penelitian ditemukan bahwa formulasi sabun cair minyak kelapa 
Formulasi Sabun Cair Dengan Kombinasi Minyak Kelapa Murni (VCO) dan Ekstrak Daun Miana (Coleus Atropurpureus)

murni (VCO) dengan variasi konsentrasi esktrak daun miana (Coleus atropurpureus) dapat menurunkan radikal bebas seperti bakteri.

Coresponden author:

Email: anitadinar1983@gmail.com

artikel dengan akses terbuka dibawah lisensi CC BY -4.0

\section{PENDAHULUAN}

Pertumbuhan penduduk yang setiap tahunnya mengalami peningkatan menyebabkan peningkatan permintaan terhadap suatu barang untuk memenuhi kebutuhan sehari-hari. Salah satu barang untuk kebutuhan sehari-hari yang cukup penting adalah produk perawatan kulit berupa sabun cair. Berdasarkan data Badan Pusat Statistik (BPS) dari tahun 2004-2009, terjadi peningkatan permintaan akan sabun cair yang ditandai dengan peningkatan data produksi, konsumsi, impor, dan ekspor sabun. Dari data Badan Pusat Statistik (BPS) tersebut dapat dilihat terjadi peningkatan konsumsi sabun pada tahun 2004 sebesar 55.832,930 ton kemudian tahun 2009 sebesar 101.631,090 ton (Achmad, S.A., 1986).

Saat ini ditemukan berbagai variasi jenis sabun yang beredar di pasaran. Sabun padat transparan salah satunya merupakan inovasi sabun yang menjadikan sabun lebih menarik dengan busa yang lebih halus dibandingkan dengan sabun opaque yang tidak transparan (BPS, 2009). Berbagai hal yang dapat mempengaruhi transparansi sabun yaitu kandungan alkohol, gula, dan gliserin dalam sabun. Adanya kandungan gliserin dalam sabun sangat baik untuk kulit karena berfungsi sebagai pelembab pada kulit dan membentuk fasa gel pada sabun. Selain itu jenis sabun lain yang saat ini banyak diproduksi karena penggunaanya lebih praktis dan bentuk yang menarik dibandingkan bentuk sabun lain adalah sabun cair. Sabun cair memiliki kelebihan jika dibandingkan dengan dengan sabun padat yaitu sabun mandi cair mudah disimpan sehinggan mudah dibawa, penampilan kemasan yang eksklusif dan tidak mudah rusak atau kotor (Setyoningrum, 2010).

Untuk menghasilkan sabun dengan kualitas yang baik maka pemilihan jenis minyak yang akan digunakan sebagai bahan baku pembuatan sabun merupakan hal yang sangat penting Asam lemak dan alkali merupakan dua komponen utama bahan dasar penyusun sabun. Setiap jenis asam lemak akan memberikan sifat yang berbeda pada sabun sehingga pemilihan jenis asam lemak menentukan karakteristik sabun yang dihasilkan (Darwis, dkk., 2013).

Menurut Setyoningrum (2010) minyak kelapa murni (VCO) merupakan salah satu minyak nabati yang sudah diketahui memiliki efek penyabunan yang baik. Minyak kelapa murni (VCO) memiliki sifat mudah tersaponifikasi (tersabunkan). Dalam minyak kelapa murni (VCO) terkandung asam lemak yang paling dominan sebesar 52\% yaitu asam laurat. Asam laurat memiliki kelarutan yang tinggi sehingga sangat memiliki peranan pada saponifikasi selain itu juga menghasilkan pembusaan 
yang sangat baik untuk produk sabun (Yunita. 2009).

Penambahan ekstrak bahan alami sebagai campuran dalam pembuatan sabun juga dapat meningkatkan manfaat dari sabun yang digunakan. Bahan campuran yang digunakan dalam proses pembutan sabun pada penelitian ini adalah ekstrak daun miana (Coleus atropurpereus). Beberapa studi penelitian menyatakan bahwa senyawa aktif antimikrobial daun miana (Coleus atropurpereus) yaitu berupa flavonoid, saponin, steroid, tanin, minyak atsiri, eugenol, senyawa polifenol, kaloid, etil salisilat, kalsium oksalat, senyawa rosmarinic acid (RA) (Ridwan, 2005), Qinlong et all., 2015).

Dari hasil penelitian menunjukkan bahwa aktivitas penghambatan ekstrak etanol daun miana (Coleus atropurpereus) terhadap pertumbuhan bakteri Escherichia coli lebih peka bila dibandingkan dengan Staphylococcus aureus. Hal ini disebabkan karena adanya perbedaan struktur dinding sel kedua jenis bakteri tersebut. Staphylococcus aureus merupakan bakteri gram positif yang memiliki dinding sel dengan beberapa lapisan peptidoglikan yang membentuk struktur yang tebal dan kaku serta mengandung substansi dinding sel yang disebut asam teikoat, sedangkan dinding sel bakteri Gram negatif Escherichia coli terdiri atas satu atau lebih lapisan peptidoglikan yang tipis dan membran di bagian luar lapisan peptidoglikan. Dinding sel bakteri Gram negatif lebih rentan terhadap guncangan fisik berupa pemberian antibiotik atau bahan antibakteri lainnya karena hanya mengandung sedikit lapisan peptidoglikan dan tidak mengandung asam teikoat. Selain itu, perbedaan struktur dinding sel inilah yang menyebabkan kedua jenis bakteri tersebut memberikan respon terhadap pewarnaan Gram. Dalam penelitian Deby (2013), aktivitas antibakteri daun miana (Coleus atropurpereus) diduga karena adanya kandungan senyawa-senyawa berkhasiat, seperti flavonoid, polifenol, saponin, alkaloid dan minyak atsiri.

Berdasarkan pemaparan di atas, maka penelitian ini dilakukan untuk membuat formulasi penggabungan kandungan antara asam laurat pada minyak kelapa murni (VCO) dan senyawa aktif pada ekstrak daun miana pada pembuatan sabun cair yang dapat menjaga kulit dari radikal bebas seperti bakteri.

\section{BAHAN DAN METODE}

A. Waktu dan Tempat

Penelitian ini dilaksanakan pada bulan April - Mei 2021 di Laboratorium Kimia dan Laboratorium Bakteriologi Program Studi Teknologi Laboratorium Medis, Politeknik Kesehatan Muhammadiyah Makassar.

Alat yang digunakan yaitu timbangan digital, beaker glass, gelas ukur, magnetic stirrer, thermometer, tabung reaksi, pipet ukur, pipet tetes, cawan petri, penangas air, lemari inkubator, oven, parut kelapa, centrifuge, saringan kelapa, kulkas, cawan, dan erlenmeyer.

Bahan yang digunakan antara lain ekstrak daun miana, Minyak Kelapa murni (VCO), $\mathrm{KOH}$ $40 \%$, gliserin, akuades, propilen glikol, Nutrien agar.

Semua alat-alat gelas yang digunakan dicuci terlebih dahulu lalu disterilkan dengan oven suhu 
Formulasi Sabun Cair Dengan Kombinasi Minyak Kelapa Murni (VCO) dan Ekstrak Daun Miana (Coleus Atropurpureus)

(Anita, Nurul Ni'ma Azis, Darmawaty Rauf, Salwa Sahur)

180o C selama 1 jam. Sedangkan alat-alat non gelas dicuci dengan air mengalir lalu dikeringkan dan dismpan pada tempat yang bersih. Selanjutnya menyiapkan semua bahan yang dipergunakan lalu ditimbang sesuai dengan kebutuhan.

B. Pembuatan Reagen

1. Pembuatan $\mathrm{KOH} 40 \%$

a. Menyiapkan alat dan bahan yang dibutuhkan

b. Menimbang padatan $\mathrm{KOH}$ sebanyak 40 gram

c. Dipindahkan ke dalam gelas kimia kemudian ditambahkan air sebanyak $90 \mathrm{~mL}$

d. Mengaduk larutan, hingga $\mathrm{KOH}$ terlarut sempurna.

2. Pembuatan Virgin Coconut Oil (VCO)

a. Menyediakan 10 butir kelapa yang sudah tua

b. Melakukan pemarutan pada daging buah kelapa.

c. Memeras kelapa yang sudah diparut dan didapatkan santan kental.

d. Santan kental dibekukan semalaman di dalam freezer.

e. Mengeluarkan santan dan diamkan lebih kurang 3 jam (sampai mencair)

f. Memasukkan santan ke dalam tabung sentrifus.

g. Sentrifugasi dengan kecepatan penuh \pm 11000 ppm selama 30 menit.

h. Minyak akan terpisah dengan endapannya. Ambil minyak dengan pipet tetes secara hatihati dan saring dengan kertas saring.

C. Pembuatan Formulasi Sabun cair Minyak Kelapa Murni (VCO) dengan Penambahan Ekstrak Daun Miana

Penelitian ini menggunakan metode eksperimental laboratorium yaitu membuat tiga jenis formulasi sabun cair. Jenis perlakuan dilakukan dengan mencampurkan Minyak Kelapa murni (VCO) dengan penambahan esktrak daun miana pada formulasi A, B, C seperti yang disajikan pada Tabel 1 di bawah ini.

Tabel 1. Formulasi Sabun cair Minyak Kelapa murni (VCO) dengan Penambahan Ekstrak daun Miana

\begin{tabular}{llll}
\hline Bahan & Perlakuan & & \\
\hline & $\mathrm{A}(0 \% \mathrm{~b} / \mathrm{b})$ & $\mathrm{B}(10 \% \mathrm{~b} / \mathrm{b})$ & $\mathrm{C}(15 \% \mathrm{~b} / \mathrm{b})$ \\
\hline Minyak Kelapa Murni (VCO) & 100 & 90 & 85 \\
\hline Estrak daun miana (gr) & 0 & 10 & 15 \\
\hline Larutan KOH 40 \% (gr) & 35 & 35 & 35 \\
\hline Gliserin (gr) & 60 & 60 & 60 \\
\hline Propilen glikol (gr) & 35 & 35 & 35 \\
\hline
\end{tabular}

D. Proses Pembuatan Sabun Menggunakan Metode Panas

Pada penelitian ini dilanjutkan dengan pembuatan sabun dengan metode panas menggunakan formulasi sabun cair yang telah ditetapkan. Minyak kelapa murni (Virgin Coconut Oil) dan esktrak 
daun miana ditempatkan di dalam beaker glass dipanaskan di atas magnetic stirrer. Pemanasan dilakukan hingga campuran minyak bersuhu $50-70^{\circ} \mathrm{C}$.

Selanjutnya larutan $\mathrm{KOH} 40 \%$ dimasukkan kemudian dilakukan pengadukan hingga homogen dengan kecepatan putar 350-700 rpm. Setelah terbentuk adonan sabun, langkah selanjutnya adalah mendiamkan adonan sabun pada suhu ruang $\left(25-27^{\circ} \mathrm{C}\right)$ dalam keadaan tertutup selama 6-10 jam. Selanjutnya dilakukan dilusi atau pencairan menggunakan akuades, gliserin, dan propilen glikol agar menjadi sabun cair.

Proses dilusi pada tahap awal dilakukan dengan mencampurkan 60 gram gliserin ke dalam beaker glass $500 \mathrm{~mL}$ lalu dipanaskan di atas hot plate dengan suhu $50-70^{\circ} \mathrm{C}$ dengan kecepatan $125-$ $360 \mathrm{rpm}$. Selanjutnya adonan sabun cair dimasukkan sedikit demi sedikit ke dalamnya. Setelah 2-3 jam proses pengadukan, sebanyak 35 gram propilen glikol dimasukkan ke dalam sabun cair dan diaduk hingga semua campuran menjadi homogen.

E. Pengujian Bakteriologis

Untuk pengujian bakteriologis dilakukan kepada 15 orang panelis yang dibagi dalam tiga kelompok perlakuan menggunakan metode angka lempeng total (ALT) pada media nutrien agar.

Kelompok I terdiri dari 5 orang panelis. Masing-masing panelis diminta meletakkan telapak tangannya pada permukaan nutrient agar setelah itu diminta melakukan cuci tangan menggunakan sabun cair formulasi A. Setelah itu panelis diminta kembali untuk meletakkan telapak tangannya pada permukaan nutrient agar yang berbeda. Selanjutnya masing-masing nutrient agar yang sudah diberi perlakuan sebelum dan sesudah mencuci tangan dengan sabun cair diinkubasi selama 1 X 24 jam Setelah 1X24 jam dilakukan pengamatan dan menghitung jumlah bakteri yang tumbuh.

Kelompok II terdiri dari 5 orang panelis. Masing-masing panelis diminta meletakkan telapak tangannya pada permukaan nutrient agar setelah itu diminta melakukan cuci tangan menggunakan sabun cair formulasi B. Setelah itu panelis diminta kembali untuk meletakkan telapak tangannya pada permukaan nutrient agar yang berbeda. Selanjutnya masing-masing nutrient agar yang sudah diberi perlakuan sebelum dan sesudah mencuci tangan dengan sabun cair diinkubasi selama 1 x 24 jam Setelah 1 x 24 jam dilakukan pengamatan dan menghitung jumlah bakteri yang tumbuh.

Kelompok III terdiri dari 5 orang panelis. Masing-masing panelis diminta meletakkan telapak tangannya pada permukaan nutrient agar setelah itu diminta melakukan cuci tangan menggunakan sabun cair formulasi C. Setelah itu panelis diminta kembali untuk meletakkan telapak tangannya pada permukaan nutrient agar yang berbeda. Selanjutnya masing-masing nutrient agar yang sudah diberi perlakuan sebelum dan sesudah mencuci tangan dengan sabun cair diinkubasi selama 1 x 24 jam Setelah 1 x 24 jam dilakukan pengamatan dan menghitung jumlah bakteri yang tumbuh.

\section{HASIL PENELITIAN}


Formulasi Sabun Cair Dengan Kombinasi Minyak Kelapa Murni (VCO) dan Ekstrak Daun Miana (Coleus Atropurpureus)

(Anita, Nurul Ni'ma Azis, Darmawaty Rauf, Salwa Sahur)

Berdasarkan hasil penelitian yang telah dilakukan pada bulan Mei 2021 di Laboratorium Kimia dan Laboratorium Bakteriologi Politeknik Kesehatan Muhammadiyah Makassar diperoleh hasil sebagai berikut:

1. Formulasi Sabun cair Berbasis Minyak Kelapa murni (VCO) dengan Penambahan Ekstrak daun Miana

Untuk pembuatan sabun cair Minyak Kelapa murni (VCO) dengan penambahan ekstrak daun miana menggunakan formulasi di bawah ini:

Tabel 2. Formulasi Sabun cair Minyak Kelapa murni (VCO) dengan Penambahan Ekstrak daun Miana

\begin{tabular}{lccc}
\hline Bahan & \multicolumn{3}{c}{ Perlakuan } \\
\hline & $\mathbf{A}(\mathbf{0 \%} \mathbf{b} / \mathbf{b})$ & $\mathbf{B}(\mathbf{1 0 \%} \mathbf{b} / \mathbf{b})$ & $\mathbf{C}(\mathbf{1 5 \%} \mathbf{b} / \mathbf{b})$ \\
\hline Virgin Coconut Oil (VCO) & 100 & 90 & 85 \\
\hline Estrak daun miana & 0 & 10 & 15 \\
\hline Larutan KOH 40 \% (gr) & 35 & 35 & 35 \\
\hline Gliserin (gr) & 60 & 60 & 60 \\
\hline Propilen glikol (gr) & 35 & 35 & 35 \\
\hline
\end{tabular}

Setelah dilakukan pembuatan formulasi sabun cair Minyak Kelapa Murni (VCO) dengan penambahan esktrak daun miana diperoleh hasil di bawah ini:

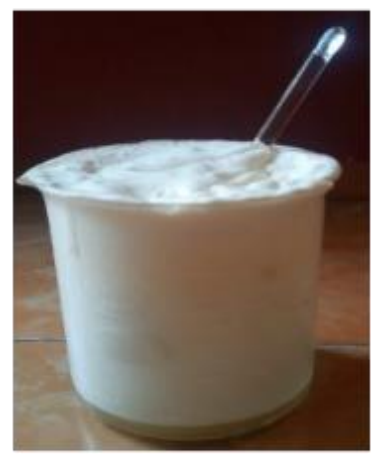

Gambar 1. Pencampuran Formulasi Sabun Cair

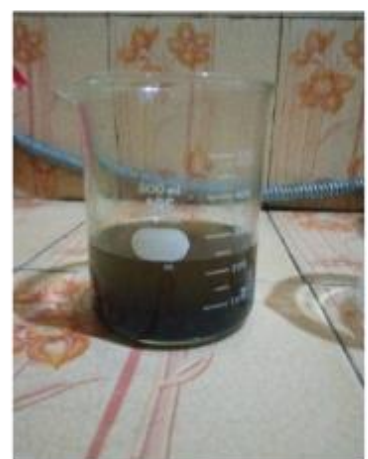

(I)

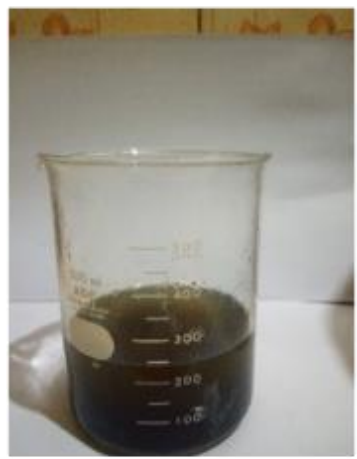

(II)

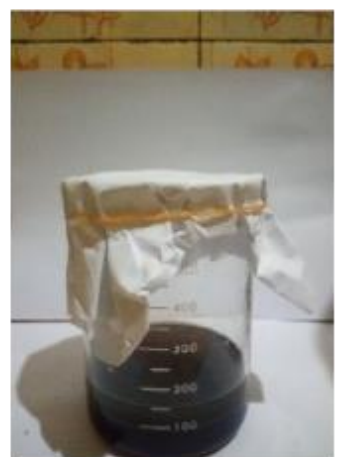

(III)

Gambar 2. Formulasi Sabun Cair 
Setelah dilakukan percampuran sabun dilanjutkan lagi pada tahap pengujian sabun cair secara mikrobiologis kepada 15 panelis. Adapun hasil dari pengujian sabun cair secara mikrobiologis dapat dilihat pada tabel di bawah ini:

Tabel 3. Hasil pengujian bakteriologis formulasi sabun cair menggunakan metode Angka Lempeng Total (ALT)

\begin{tabular}{|c|c|c|c|}
\hline \multirow[t]{2}{*}{ No } & \multirow[t]{2}{*}{ Kode Sampel } & \multicolumn{2}{|c|}{ Jumlah Koloni Yang Tumbuh } \\
\hline & & Sebelum Cuci tangan & Sesudah Cuci tangan \\
\hline \multicolumn{4}{|c|}{ Formulasi I } \\
\hline 1 & NA 1a & 21 koloni & 10 koloni \\
\hline 2 & NA1b & 18 kolonu & 10 koloni \\
\hline 3 & NA 1c & 16 koloni & 7 koloni \\
\hline 4 & NA 1d & TBUD & 11 koloni \\
\hline 5 & NA 1e & TBUD & 4 koloni \\
\hline \multicolumn{4}{|c|}{ Formulasi II } \\
\hline 1 & NA IIa & 26 koloni & 17 koloni \\
\hline 2 & NA II b & TBUD & 25 koloni \\
\hline 3 & NA IIc & 15 koloni & 7 koloni \\
\hline 4 & Na IId & 18 koloni & 10 koloni \\
\hline 5 & $\mathrm{Na}$ II e & TBUD & 15 koloni \\
\hline \multicolumn{4}{|c|}{ Formulasi III } \\
\hline 1 & NA IIIa & 8 koloni & 3 koloni \\
\hline 2 & NA IIIb & TBUD & 10 koloni \\
\hline 3 & NA IIIc & TBUD & 3 koloni \\
\hline 4 & NA IIId & 8 koloni & 3 koloni \\
\hline 5 & NA IIIe & 13 koloni & 5 koloni \\
\hline
\end{tabular}

Dari hasil uji bakteriologis pada formulasi I setelah dilakukan pengujian pada kelima panelis diperoleh bahwa untuk formulasi I rata-rata terjadi perubahan jumlah koloni bakteri sesudah mencuci tangan dibandingkan dengan sebelum mencuci tangan.

Begitu pula untuk sabun cair formulasi II setelah setelah dilakukan pengujian pada kelima panelis diperoleh bahwa rata-rata terjadi perubahan jumlah koloni jumlah koloni bakteri sesudah mencuci tangan dibandingkan dengan sebelum mencuci tangan.

Untuk sabun cair formulasi III setelah setelah dilakukan pengujian pada kelima panelis diperoleh bahwa rata-rata terjadi perubahan jumlah koloni jumlah koloni bakteri sesudah mencuci tangan dibandingkan dengan sebelum mencuci tangan.

\section{PEMBAHASAN}

Minyak Kelapa Murni (VCO) sering digunakan dalam pembuatan sabun karena sifatnya yang sangat mudah diabsorpsi oleh kulit, sehingga membuat kulit menjadi lembut, lembab, dan tidak menimbulkan iritasi pada kulit. Minyak Kelapa Murni (VCO) bersifat lebih awet dan tidak mudah tengik (Mangoenkoekardjo dan Semangun, 2005). Selain itu penggunaan minyak kelapa murni (VCO) dalam pembuatan sediaan sabun sehingga meminimalkan terjadinya iritasi pada kulit karena 
Formulasi Sabun Cair Dengan Kombinasi Minyak Kelapa Murni (VCO) dan Ekstrak Daun Miana (Coleus Atropurpureus)

(Anita, Nurul Ni'ma Azis, Darmawaty Rauf, Salwa Sahur)

kandungan emolient dalam minyak kelapa murni (VCO) sehingga kulit akan terasa halus dan sediaan lebih acceptable (Elisabeth, 2010).

Pada penelitian ini menggunakan formulasi minyak kelapa murni (VCO) dengan tiga kombinasi. Penggunaan minyak kelapa murni (VCO) sebagai bahan dasar pembuatan sabun pada penelitian ini karena minyak kelapa murni (VCO) adalah minyak yang paling kaya dengan kandungan asam lemak yang menguntungkan kulit dibandingkan dengan minyak lainnya dan warna minyak kelapa murni (VCO) yang bening putih jernih dan mudah larut dalam air. Asam lemak yang paling dominan dalam minyak kelapa murni (VCO) adalah asam laurat $\left(\mathrm{HC}_{12} \mathrm{H}_{23} \mathrm{O}_{2}\right)$. Kandungan utama pada minyak kelapa murni (VCO) adalah asam laurat 46\% (Depperin, 2007). Asam laurat sangat diperlukan dalam pembuatan sabun karena mampu memberikan sifat pembusaan yang sangat baik dan lembut untuk produk sabun. Menurut Alamsyah (2005), asam laurat merupakan asam lemak jenuh rantai sedang yang bersifat antimikroba (antivirus, antibakteri, dan antijamur).

Selain itu pada penelitian ini digunakan penambahan esktrak daun miana (Coleus atropurpureus). Seperti diketahui bahwa salah satu tanaman yang berpotensi sebagai antibakteri adalah daun miana (Coleus atropurpureus). Kandungan senyawa metabolit sekunder yang terdapat dalam daun miana berfungsi sebagai antibakteri antara lain memiliki warna merah kehitaman yang sangat berkhasiat. Bagian daunnya mengandung minyak atsiri, saponin, flavonoid dan polivenol, zatzat alkaloida, mineral serta sedikit lendir. Kandungan kimia tersebut merupakan metabolit sekunder tumbuhan. Senyawa ini merupakan kimia alami yang berguna bagi tumbuhan sendiri dan bagi lingkungannya, termasuk memiliki khasiat obat untuk manusia.

Dari hasil peneliatian Auliawan dan Bambang (2014) mengenai uji fitokimia terhadap ekstrak daun miana menunjukkan test positif terhadap keberadaan alkaloid, flavonoid, saponin dan tanin serta negatif untuk uji steroid/triterponoid.

Pada hasil pengujian bakteriologis ini ditemukan hasil bahwa sabun cair kombinasi formulasi minyak kelapa murni (VCO) dan ekstrak daun miana (Coleus atropurpureus) efektif dapat menurunkan radikal bebas berupa pertumbuhan bakteri pada media nutrient agar. Hal ini terbukti bahwa terjadi penurunan pertumbuhan bakteri setelah dilakukan mencuci tangan menggunakan sabun cair tersebut.

Salah satu tindakan sanitasi yang dapat dilakukan untuk memutuskan mata rantai penyebaran kuman baik bakteri maupun virus adalah dengan mencuci tangan, membersihkan tangan dan jari jemari menggunakan air dan sabun. Selain itu mencuci tangan dengan sabun (CTPS) dikenal juga sebagai salah satu upaya pencegahan penyakit. Hal ini dilakukan karena tangan sering kali menjadi agen yang membawa kuman baik bakteri maupun virus dan menyebabkan patogen berpindah dari satu orang ke orang lain, baik dengan kontak langsung ataupun kontak tidak langsung (menggunakan permukaan-permukaan lain seperti handuk, gelas). 
Menggunakan sabun dalam mencuci tangan sebenarnya menyebabkan orang harus mengalokasikan waktunya lebih banyak saat mencuci tangan, tetapi penggunaan sabun menjadi efektif karena lemak dan kotoran yang menempel akan terlepas saat tangan digosok dan bergesek dalam upaya melepasnya. Di dalam lemak dan kotoran yang menempel inilah kuman penyakit hidup.

\section{KESIMPULAN DAN SARAN}

Dari hasil penelitian ditemukan bahwa formulasi sabun cair minyak kelapa murni (VCO) dengan variasi konsentrasi esktrak daun miana (Coleus atropurpureus) dapat menurunkan radikal bebas seperti bakteri.

\section{UCAPAN TERIMA KASIH}

Ucapan terimakasih peneliti kepada Direktur Politeknik Kesehatan Muhammadiyah Makassar yang telah mendanai penelitian internal kami. Kami juga mengucapkan terimakasih banyak kepada Lembaga Penelitian dan Pengabdian Kepada Masyarakat Politeknik Kesehatan Muhammadiyah Makassar yang telah memfasilitasi sehingga kami peneliti mendapatkan pendanaan penelitian internal Politeknik Kesehatan Muhammadiyah Makassar.

\section{DAFTAR PUSTAKA}

Achmad, S.A. 1986.Kimia Organik Bahan Alam 1. Penerbit Karunika Jakarta, Universitas Terbuka. 148 hal.

Alamsyah, A. N., 2015. Virgin Coconut Oil: Minyak Penakluk Aneka Penyakit, Jakarta: Agromedia Pustaka. Hal 67-94.

Auliawan, R., B Cahyono, 2014. Efek Hidrolisis Ekstrak Daun Iler (Coleus scutellarioides) Terhadap Aktivitas Inhibisi Enzim $\alpha$-glukosidase. Jurnal sains dan Matematika.Vol 22(1): 15-19.

Badan Pusat Statistik. 2009. Data Konsumsi, Produksi, Ekspor, dan Impor Sabun cair Padat di Indonesia. Jakarta.

Badan Standarisasi Nasional., 1994. Standar Mutu Sabun cair. SNI 06-3532-1994. Dewan Standardisasi Nasional. Jakarta.

Darwis, dkk. 2013. Ekstraksi dan Uji Antioksidan Senyawa Antosianin Dari Daun Miana (Coleus scutellarioides L (Benth).) serta Aplikasi Pada Minuman. Jurnal Kimia Unand (ISSN No. 2303-3401), Volume 2 Nomor 2, Mei 2013 44. Laboratorium Kimia Bahan Alam. Jurusan Kimia FMIPA. Universitas Andalas

Deby, dkk, 2013, UJI AKTIVITAS ANTIBAKTERI EKSTRAK ETANOL DAUN MAYANA (Coleus atropurpureus [L] Benth) TERHADAP Staphylococcus aureus, Escherichia coli DAN Pseudomonas aeruginosa SECARA IN-VITRO, Program Studi Farmasi FMIPA UNSRAT Manado.

Departemen Perindustrian. 2007. Gambaran Sekilas Industri Minyak Kelapa Sawit. Jakarta: Pusat Data dan Informasi Departemen Perindustrian 
Formulasi Sabun Cair Dengan Kombinasi Minyak Kelapa Murni (VCO) dan Ekstrak Daun Miana

(Coleus Atropurpureus)

(Anita, Nurul Ni'ma Azis, Darmawaty Rauf, Salwa Sahur)

Elisabeth N. 2010. Optimasi Formula Sabun Padat Transparan Dengan Minyak VCO dan Surfaktan Cocoamidoprophyl Betaine: Aplikasi Desain Faktorial. [Skripsi]. Yogyakarta. Universitas Sanata Dharma

Harborne JB. 1996. Metode Fitokimia. Terjemahan K Padmawinata. Penerbit ITB, Bandung. 354 hal

Ipotnews, Indo Premier. (2011). Kenaikan harga produk sabun. Terdapat pada: https://www.ipotnews.com/m/article.php?jdl=Unilever_Naikkan_Harga_Produk_Sabun_10\% 25

Karo, A.Y.K. (2011). Pengaruh penggunaan kombinasi jenis minyak terhadap mutu sabun transparan. Skripsi. Institut Pertanian Bogor. Bogor.

Mangoenkoekardjo S, Semangun H. 2005. Manajemen Agribisnis Kelapa Sawit. Yogyakarta: Gadjah Mada University Press.

Niken, et all, 2021, Pembuatan Sabun Cair Berbasis Virgin Coconut Oil (VCO) Dengan Penambahan Minyak Lavender Sebagai Essential Oil Pencegahan Penyakit Covid-19, Program Studi Teknologi Laboratorium Medik, Stikes Syedza Saintika.

Rahadiana, P., Andayani L.S. 2014. Pabrik Sabun Transparan Beraroma Terapi dari Minyak Jarak dengan Proses Saponifikasi Trigliserida Secara Kontinyu. Program Studi D3 Teknik Kimia FTI-ITS.

Ridwan, 2005, Kandungan Kimia Berbagai Ekstrak Daun Miana (Coleus blumei Benth) dan Efek Anthelmintiknya Terhadap Cacing Pita Pada Ayam. J.II.Per.Indon. Volume II (2).

Setyoningrum, E. N. M. 2010. Optimasi Formula Sabun Transparan dengan Fasa Minyak Virgin Oil dan Surfaktan Cocomidropyl Betaine: Aplikasi Desain Faktorial. Skripsi. Universitas Sanata Dharma. Yogyakarta.

Sutarmi \& Rozalin, H. (2015). Taklukan Penyakit dengan VCO (Virgin Coconut Oil). Penebar Swadaya: Bogor.

Syamsuhidayat SS dan Hutapea JR. 1991. Inventaris Tanaman Obat Indonesia. Departemen Kesehatan RI, Jakarta

Widiyanti, Yunita. 2009. Kajian Pengaruh Jenis Minyak terhadap Mutu Sabun Transparan. Fakultas Teknologi Pertanian, IPB. Bogor.

Zhu, Qinlong et all., 2015. Isolation and Functional Characterization of a Phenylalanine AmmoniaLyase Gene (SsPAL1) from Coleus (Solenostemon scutellarioides (L.) Codd). Molecules 2015, 20, 16833-16851 